\title{
Penggunaan Beberapa Komposisi Spektrum Led Pada Potensi Dan Hasil Hidroponik Indoor Selada Keriting Hijau
}

\author{
Daru Nurdianna ${ }^{2)}$, Retno Bandriyati Arni Putri ${ }^{1)}$, Dwi Harjoko ${ }^{1)}$
}

\begin{abstract}
This study aims to determine the differences in the growth response of green curly lettuce to the differentiation treatment of LED lighting with different spectrum in indoor hydroponics. The research was conducted from October to November 2017. The experimental design used was experimental with 1 lighting factor with 5 levels, there are sunlight (P0), LED $20 \%$ blue: $80 \%$ red (P1), LED $80 \%$ blue: $20 \%$ red (P2), $50 \%$ blue LED: $50 \%$ red (P3), and $100 \%$ white daylight (P4). Observational variables included plant height, leaf number, leaf area, leaf color, total wet weight, leaf wet weight, wet root weight and dry weight of the plant. The result of this experiment showed that LED irradiation have affect the treatment are plant height, leaf number, leaf area, chlorophyll content, fresh weight of harvest, root length, and dry weight of brackets. While those that have no significant effect are the wet weight of the roots. The results showed that between LED irradiation treatment L1, L2, L3, and L4 showed that treatment L2 with $80 \%$ blue spectrum composition: $20 \%$ red showed better growth based on: high plant, chlorophyll content, and root length. Treatment with L4 with white LED showed better growth based on the number of leaves, leaf area, fresh weight of harvest, root wet weight, and dry weight of total biomass. The results below the sunlight better than the LED irradiation treatment, because the intensity of LED far low and lack of controlled environmental conditions technology and management for growing lettuce. In all of LED treatment still looked etiolation because light intensity was not optimal yet.
\end{abstract}

Keywords: Indoor Hydroponics, Artificial Light, Vertikal Farming

\section{PENDAHULUAN}

Dalam beberapa dekade ini penelitian terhadap penggunaan pencahayaan buatan untuk memproduksi tanaman sayuran sudah banyak dikembangkan, terutaman negara-negara maju yang memiliki areal perkotaan padat yang luas. Kremes et al (2007) banyak perhatian telah diberikan kepada pencahayaan solidstate dengan penekanan pada LED (Light Emiting Diodes). Penggunaan lampu LED memiliki potensi salah satu kemajuan terbesar dalam pencahayaan hortikultura dalam beberapa dekade dan LED memiliki keunggulan dapat mengatur komposisi spektrum yang dihasilkan (Morrow 2008). Keunggulan lain LED adalah intensitas tinggi dan hemat energi LED telah banyak digunakan untuk memaksimalkan pertumbuhan tanaman (Sarkar dan Majumder 2015).

Adanya permintaan sayuran segar diperkotaan padat dan persoalan lahan, cuaca, dan urbanisasi menjadi latar belakang diperlukannya produksi sayuran segar di tengah-tengah kota. Salah satu yang dapat menjawab persoalan tersebut adalah teknik pertanian hidroponik berbasis vertical indoor farming yang menggunakan lampu buatan sebagai pencahayaan utama pengganti sinar matahari di dalam ruang.

1)Lecturer Staff of Study Program of Agrotechnology, Faculty of Agriculture, Sebelas Maret University (UNS) on Surakarta.

2)Undergraduate Student of Study Program of Agrotechnology, Faculty of Agriculture, Sebelas Maret University (UNS) on Surakarta.

Contact Author: Retnabandriyati@uns.staff.ac.id
Tumbuhan dengan bantuan cahaya matahari dan pigmen fotosintesis akan menghasilkan karbohidrat dan melepaskan oksigen. Cahaya matahari meliputi semua warna dari spektrum tampak dari merah hingga ungu, tetapi tidak semua panjang gelombang dari spektrum tampak diabsorbsi (Sasmitamihardja dan Siregar 1996). Cahaya terpancarkan dari sumbernya memancarkan energi dalam bentuk gelombang yang merupakan bagian dari kelompok gelombang elektromagnetik dan cahaya alam dari matahari terdiri dari cahaya tidak tampak dan cahaya tampak (Saputro et al 2013). Cahaya tampak disebut juga PAR (Photosynthesis Active Radiation) menunjuk rentang spektral dari radiasi matahari 400-700 nanometer. Dalam rentang inilah yang organisme fotosintetik mampu menggunakannya dalam proses fotosintesis (Carney et al 2015).

PAR cahaya matahari terdapat juga atau dapat dihasilkan juga dengan menggunakan pencahayaan lampu LED. Pertanyaan bagaimana spesifikasi spektrum dan kombinasi panjang gelombang untuk mencari produktivitas maksimal masih terbuka untuk dikaji (Olle 2013). Usaha yang dilakukan untuk mengembangkan dalam teknologi pencahayaan, dapat menjadikan usaha positif untuk memperoleh cahaya dengan spektrum yang lebih baik (Zakrzewska 2014). Dalam diskursus pencahayaan buatan, ditemukan tidak semua cahaya digunakan tanaman, namun lebih spesifik lagi ternyata cahaya spektrum merah dan biru yang efisien digunakan untuk fotosintesis dari pada seluruh spektrum cahaya tampak (Carney et al 2015, Syafriyudin 2015, Aldaghi et al 2016). 
Selain fotosintesis, proses bio-kimia yang terlibat dalam diskursus ini adalah fotorespirasi. Efek dari spektrum PAR untuk fiksasi $\mathrm{CO}_{2}$ berbeda di bawah lingkungan yang terbatas cahaya dan jenuh cahaya. $\mathrm{Di}$ bawah kondisi terbatas cahaya, efisiensi penggunaan cahaya linier terhadap kejadian cahaya yang diserap oleh daun (Hogewoning 2010). Evolusi tipe-tipe fotosintesis seperti C4 dan CAM merupakan respons terhadap menurunnya rasio $\mathrm{CO}_{2}$ dan $\mathrm{O}_{2}$ dan kondisi atmosfir dengan radiasi yang intensif (Ai 2012).

Dalam penelitian ini dipilih menggunakan lampu LED karena memiliki keunggulan efisiensi energi dan sedikit sekali mengelurkan panas dan dapat diatur spektrum warna yang akan dihasilkan. LED adalah suatu semikonduktor yang memancarkan cahaya monokromatik atau bisa diartikan sebagai dioda yang memancarkan cahaya bila dialirkan arus listrik (Kurniawati 2010). Dalam mengurangi penggunaan energi untuk produksi tanaman, LED termasuk efisien dalam pemancaran cahaya karena mengkonsumsi energi yang rendah (Kobayashi 2013).

Pertumbuhan maksimum tanaman dapat dibantu dengan pencahayaan dengan panjang gelombang dari lampu yang sesuai (Restiani et al 2015). Lampu LED RB (red-blue) lebih efektif daripada lampu LED putih dalam memfasilitasi pertumbuhan selada (Bian 2016). Respon fisiologis yang disebabkan oleh pemberian terhadap panjang gelombang cahaya yang berbeda pada selada bervariasi dengan genotip benih dan dengan waktu paparan cahaya yang diberikan (Pardo et al 2013). Tanaman membutuhkan cahaya dengan panjang gelombang 400-520 nm dan 610-720 nm panjang gelombang cahaya biru dan merah (Promratrak 2017). Dalam penelitian-penelitian sebelumnya, tanaman memberikan respon yang cukup baik pada penanaman menggunakan LED, sama seperti pada pencahayaan menggunakan Flouroscene. Tanaman terlihat sehat dan proses pertumbuhan dapat dikatakan normal (Annisa et al 2015).

Petani memiliki kendala kurangnya intensitas cahaya karena kondisi alam, maka solusi pencahayaan untuk produksi tanaman dapat menggunakan lampu LED (Lindawati 2015). Pemeliharaan ketahanan pangan semakin menantang bagi kota-kota modern yang dimana lahan subur tersedia sangat terbatas, maka sistem pertanian vertikal dalam ruangan perkotaan dapat menawarkan solusi untuk produksi tanaman sayuran (He 2015). Penelitian ini mempunyai tujuan untuk mengkaji perbedaan pengaruh dari beberapa komposisi spektrum LED pada potensi dan hasil selada keriting hijau secara hidroponik indoor. Sehingga, penelitian yang menemukan cara pengelolaan yang tepat dari radiasi dan panjang gelombang mungkin menjanjikan peningkatan efisiensi ekonomi dari potensi produksi, kualitas, dan nutrisi tanaman sayuran yang ditanam di lingkungan yang terkendali (Lin 2012).

\section{BAHAN DAN METODE}

Penelitian ini dilaksanakan di Desa Pojok, Delingan Kec. Karanganyar, Kab. Karanganyar, pada ruangan tertutup, yang dilaksanakan pada bulan
Oktober - Desember 2017. Bahan yang digunakan dalam penelitian ini adalah biji selada hijau keriting Grand Rapids, garam-garam nutrisi hidroponik (kalsium nitrat, kalium nitrat, Fe-Edta, kalium dihidrofosfat, amonium sulfat, magnesium sulfat Mn-EDTA, CuEDTA, Zn-EDTA, asam borat, mangan sulfat, natrium molibdat) air, asam fosfat $\left(\mathrm{H}_{3} \mathrm{PO}_{4}\right)$ dan kalium hidroksida $(\mathrm{KOH})$. Alat yang digunakan dalam penelitian ini adalah luxmeter, klorofilmeter, TDS dan Ph meter, EC Meter, rak besi siku, instalasi kabel listrik, adaptor $12 \mathrm{~V}$, lampu LED strip SMD 2835 dan LED HPL (merah 620-660 nm, biru 450-460 nm, putih $6500 \mathrm{~K}$ ), netpot, stairofoarm, bak nutrisi, timbangan analitik dan rockwool.

Penelitian ini menggunakan rancangan experimental dengan 1 faktor 5 taraf (L). Adapun 5 perlakuan taraf tersebut sebagai berikut: Kontrol dibawah cahaya matahari (LO), lampu LED merah $80 \%$ : biru $20 \%$ (L1), lampu LED merah $50 \%$ : biru $50 \%$ (L2), lampu LED Merah $20 \%$ dan biru $80 \%$ (L3), lampu LED putih daylight 100\% (L4) kemudian diulang sebanyak 12 kali. Analisis data menggunakan uji ANOVA One Way dengan taraf kepercayaan $5 \%$ dan uji lanjut menggunakan uji Duncan.

\section{HASIL DAN PEMBAHASAN}

\section{Kondisi lingkungan}

Kondisi lingkungan sangat menentukan tanaman dapat tumbuh dengan baik atau tidak. Selain kualitas spektrum cahaya, ada aspek lingkungan lain yang bersifat esensial seperti suhu, kelembapan, $\mathrm{CO}_{2}$ dan $\mathrm{O}_{2}$. Budidaya di dalam ruangan memerlukan penggunaan cahaya buatan sebagai pengganti cahaya matahari. Intensitas dan spektrum cahaya menjadi salah satu bahasan pokok dalam pengembangan teknologi budidaya di dalam ruangan, karena setiap tanaman memiliki respon yang berbeda terhadap cahaya buatan tersebut.

Tabel 1 Intensitas cahaya

\begin{tabular}{|c|c|c|c|}
\hline Perlakuan & $\begin{array}{l}\text { Intensitas } \\
\text { (Lux) }\end{array}$ & $\begin{array}{l}\text { Komposisi } \\
\text { Spektrum }\end{array}$ & $\begin{array}{c}\text { Durasi } \\
\text { Penyinaran } \\
\text { Jam/Hari }\end{array}$ \\
\hline LO & $\begin{array}{l}591- \\
874000\end{array}$ & $\begin{array}{l}\text { Spektrum } \\
\text { Penuh }\end{array}$ & 12 \\
\hline L1 & 3580 & $\begin{array}{l}\text { Merah } 80 \% \text { : } \\
\text { biru } 20 \%\end{array}$ & 18 \\
\hline L2 & 4440 & $\begin{array}{l}\text { Merah } 20 \%: \\
\text { biru } 80 \%\end{array}$ & 18 \\
\hline L3 & 3770 & $\begin{array}{c}\text { Merah } 50 \% \text { : } \\
\text { biru } 50 \%\end{array}$ & 18 \\
\hline L4 & 8830 & $\begin{array}{c}\text { Putih Cerah } \\
\text { Daylight } \\
100 \% \\
\text { temperatur } \\
\text { warna } 6500 \\
\text { Kelvin }\end{array}$ & 18 \\
\hline
\end{tabular}

Pengamatan lingkungan meliputi intensitas cahaya, suhu dan kelembapan. Intensitas cahaya di dalam greenhouse berdasarkan Tabel 1 pada pagi hari 
berkisar antara 3760-11250 lux, siang hari berkisar antara 2910-874000 lux, dan sore hari berkisar antara 591-2431 lux. Intensitas cahaya pada rak penanaman di pagi, siang dan sore hari, intensitas cahaya L1 berkisar 3580 lux, L2 berkisar 4440 lux, L3 berkisar 3770 lux, dan L4 berkisar 8830. Intensitas cahaya perlakuan konstan dan jenuh dengan durasi pencahayaan selama 18 jam.

Suhu dan kelembapan dihitung menggunakanthermohigrograf ruang digital. Setiap hari selama 35 hari penanaman suhu dan kelembapan diambil pada pagi, siang, sore dan malam hari dan ada 3 tempat pengambilan data suhu dan kelembapan tersebut kemudian dirata-rata (Tabel 2). Suhu mempengaruhi kadar klorofil tanaman. Menurut Ginting (2008) klorofil tanaman selada meningkat pada suhu lingkungan perakaran $20-25^{\circ} \mathrm{C}$ yang berlangsung sekitar 12 jam berlaku baik pada musim kemarau maupun musim penghujan.

Tabel 2 Suhu dan kelembapan lingkungan

\begin{tabular}{|c|c|c|c|c|c|c|c|c|}
\hline \multirow{2}{*}{ Tempat } & \multicolumn{4}{|c|}{ Suhu rata-rata $\left({ }^{\circ} \mathrm{C}\right)$} & \multicolumn{4}{|c|}{ Kelembapan rata-rata (\%) } \\
\hline & 8:00 & $12: 00$ & 16:00 & $20: 00$ & $8: 00$ & $12: 00$ & $16: 00$ & $20: 00$ \\
\hline $\begin{array}{l}\text { Dalam Rak } \\
\text { Penelitian }\end{array}$ & 28,7 & 30,3 & 29,9 & 29,7 & 81,1 & 77,3 & 76,8 & 78,2 \\
\hline $\begin{array}{c}\text { Ruang } \\
\text { Penanaman }\end{array}$ & 27,6 & 30,2 & 29,6 & 28,7 & 77,9 & 77,1 & 76,1 & 79,1 \\
\hline Luar Ruang & 28,6 & 34,2 & 29 & 26,2 & 83,4 & 64 & 76,8 & 88,3 \\
\hline
\end{tabular}

\section{Pengamatan larutan nutrisi}

Pengamatan larutan nutrisi yang dilakukan meliputi memperhatikan kualitas nutrisi hidroponik, pengukuran EC (Electro-Conductivity) larutan dan pH (potentioan of Hidrogen) larutan. Pada penelitian ini EC yang digunakan pada awal penanaman yaitu $1600 \mu \mathrm{S} / \mathrm{cm}$, minggu kedua dinaikkan menjadi $2000 \mu \mathrm{S} / \mathrm{cm}$, minggu keempat $2400 \mu \mathrm{S} / \mathrm{cm}$ dan memasuki akhir panen sebesar $2800 \mu \mathrm{S} / \mathrm{cm}$. Pengukuran dengan $\mathrm{pH}$ meter dan penyetabilan $\mathrm{pH}$ agar tetap dalam kondisi optimal yakni 5,5-6,5 dilakukan seminggu sekali. Jika $\mathrm{pH}$ tinggi maka diberikan asam fosfat $\left(\mathrm{H}_{3} \mathrm{PO}_{4}\right)$ dan kalium hidroksida $(\mathrm{KOH})$ jika $\mathrm{pH}$ rendah. Kualitas nutrisi sangat penting bagi sistem hidroponik statis atau sistem tidak mengalir. Sistem statik (nutrisi tidak mengalir) ada faktor penentu keberhasilan yakni kualitas nutrisi. Jika kualitas pupuk kurang bagus atau ada beberapa hara yang mengendap, maka penyerapan hara oleh tanaman juga akan terpengaruh (Siregar 2015).

\section{Evapotranspirasi}

Perlakuan LO menghasilkan peningkatan yang paling tinggi dari semua perlakuan yakni tinggi permukaan air berkurang $1,5 \mathrm{~mm}$ pada hari ke-35, sedangkan perlakuan dibawah LED penanaman di dalam ruangan memiliki hasil yang hampir sama. Pada hari ke-35 di perlakuan L0, L1, L2, L3 dan L4 total air dalam bak penelitian menurut Gambar 1 berkurang sebanyak 22,8 mm; 7,51 mm; 8,19 mm; 7,85 mm; dan 8,26 mm. Penurunan permukaan evapotranspirasi menggambarkan kebutuhan air pada tanaman dan semakin besar tanaman selada, maka semakin banyak pula kebutuhan airnya (Restiani et al 2015).

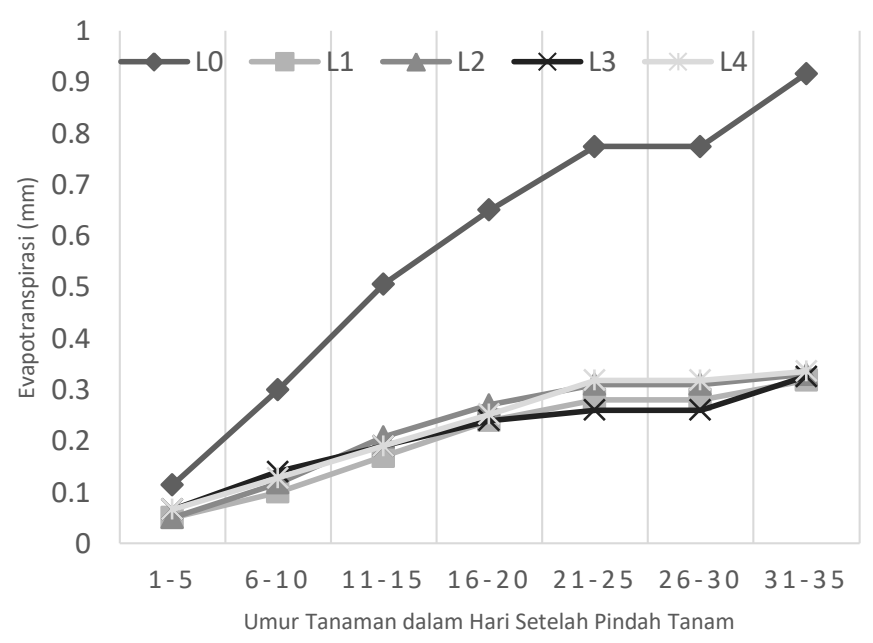

Keterangan:

LO: cahaya matahari

L1: LED merah $80 \%$ : biru $20 \%$

L2: LED merah $20 \%$ : biru $80 \%$

L3: LED merah 50\%: biru $50 \%$

L4: LED putih daylight $100 \%$ Temperatur Warna 6500 Kelvin Gambar 1 Evapotranspirasi harian

\section{Tinggi tanaman}

Perkembangan pertumbuhan setiap minggu tertinggi dari semua perlakuan adalah pada perlakuan L0 dengan hasil rata-rata $9,79 \mathrm{~cm}$, sedangkan tetinggi pada perlakuan pencahayaan LED pada perlakuan L4 dengan hasil rata-rata 7,42 ; diikuti $L 2$ dengan rata-rata $5,78 \mathrm{~cm}$; L3 rata-rata $5,20 \mathrm{~cm}$ dan $L 1$ rata-rata $4,20 \mathrm{~cm}$. (Gambar 2) menunjukkan hasil tertinggi pada perlakuan L0 dengan rerata tinggi 47,9 cm dari semua perlakuan.

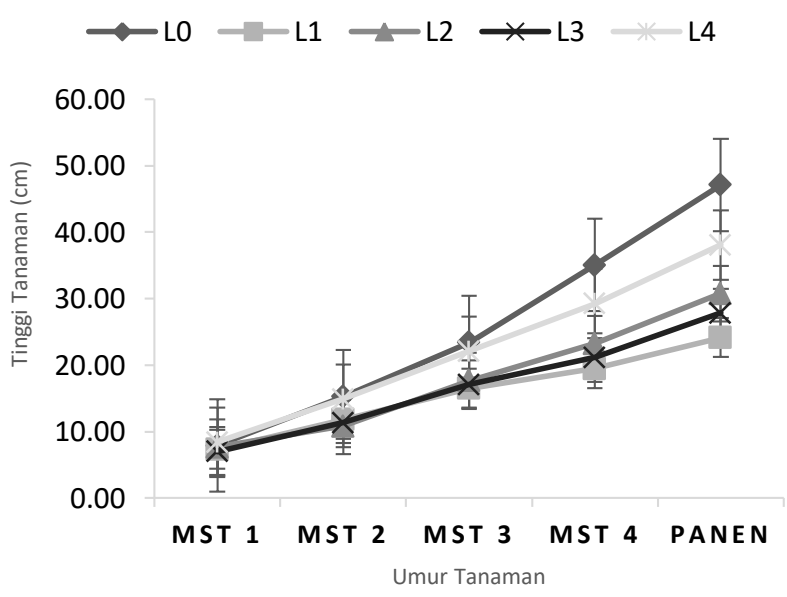

Gambar 2 Pertumbuhan tanaman (minggu)

\section{Jumlah daun}

Hasil penelitian menurut Gambar 3 menyatakan bahwa daun yang paling banyak adalah LO sebagai perlakuan pembanding di bawah cahaya matahari 
dengan hasil rata-rata 10,58. Perlakuan dibawah lampu LED terbanyak pada perlakuan L4 dengan rata-rata 10,5; kemudian L2 rata-rata 9,5; disusul L3 rata-rata 9,42; dan L1 rata-rata 8,75. Jumlah daun dari semua perlakuan menunjukkan perkembangan dan pertumbuhan yang hampir sama.

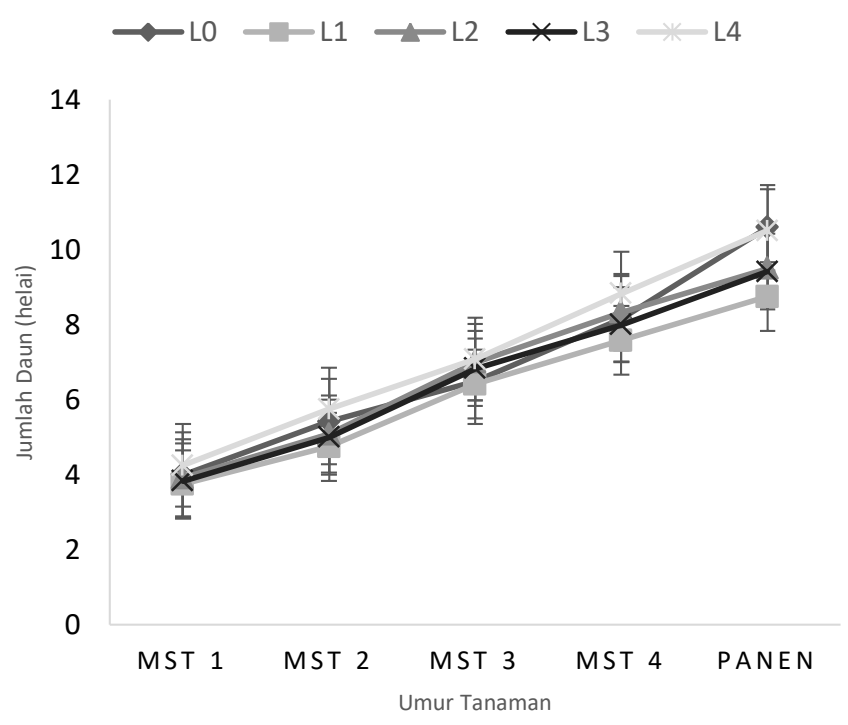

Gambar 3 Pertumbuhan jumlah daun (minggu)

\section{Luas daun}

Hasil pengukuran menyatakan luas daun yang paling luas dari seluruh perlakuan masih diperoleh tanaman dengan perlakuan pembanding L0 dibawah cahaya matahari dengan hasil pengukuran (Tabel 3) didapati luas daun 133,95 $\mathrm{cm}^{2}$, sedangkan dari perlakuan dibawah lampu LED yang paling luas adalah perlakuan L4 dengan hasil rata-rata $40,59 \mathrm{~cm}^{2}$, namun Pada Tabel 3 menunjukkan perlakuan L2 dengan ratarata luas $38,58 \mathrm{~cm}^{2}$ dan L4 tidak berbeda nyata. Perhitungan statistik deskriptif menunjukkan nilai minimal yaitu $11,1 \mathrm{~cm}^{2}$; nilai maksimal $165,74 \mathrm{~cm}^{2}$; ratarata $52,19 \mathrm{~cm}^{2}$ dan simpangan baku 44,22.

Tabel 3 Rata-rata luas daun

\begin{tabular}{ccc}
\hline Perlakuan & Pencahayaan & Luas Daun $\left(\mathrm{cm}^{2}\right)$ \\
\hline L0 & Cahaya Matahari & $133,95 \mathrm{c}$ \\
L1 & LED 80\%Merah: 20\%Biru & $19,75 \mathrm{a}$ \\
L2 & LED 20\%Merah: 80\%Biru & $38,58 \mathrm{~b}$ \\
L3 & LED 50\%Merah: 50\%Biru & $28,09 \mathrm{ab}$ \\
L4 & LED 100\% Putih & $40,59 \mathrm{~b}$
\end{tabular}

Keterangan: Angka yang diikuti huruf yang sama menunjukkan tidak berbeda nyata pada uji analisis ragam taraf $5 \%$

\section{Kandungan klorofil}

Gambar 4 menunjukkan bahwa kandungan klorofil yang paling tinggi dimiliki oleh daun perlakuan L0 dari seluruh perlakuan yakni sebanyak 13,43; sedang perlakuan di bawah cahaya LED perlakuan L2 memiliki kandungan klorofil yang paling tinggi sebanyak 11,07; diikuti L4 sebanyak 9,53; L3 sebanyak 8,78; dan L1 sebanyak 13,43. Perlakuan L3 dan L4 memiliki simbol huruf yang sama yakni $b$ yang menandakan bahwa kedua perlakuan tersebut tidak signifikan.

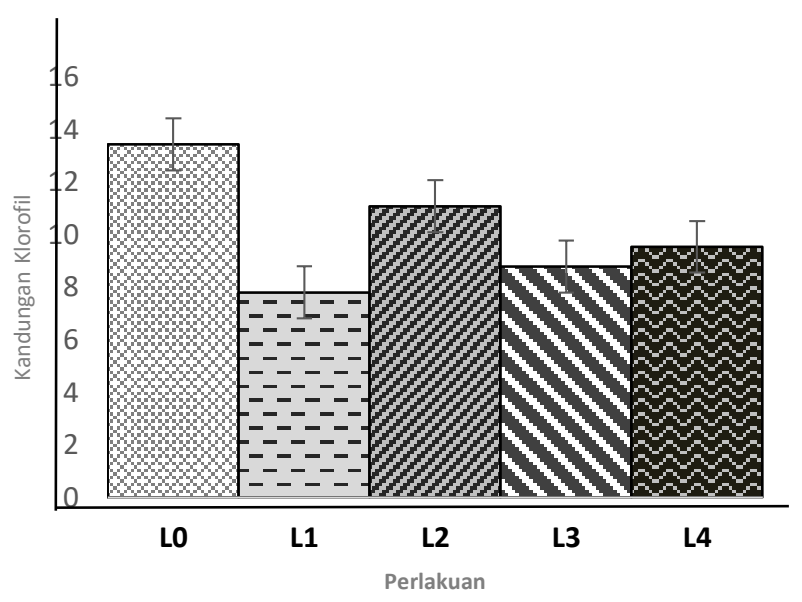

Gambar 4 Kandungan klorofil daun

\section{Bobot segar panen}

Bobot segar panen adalah berat dari tajuk atas tanaman yang berupa daun dan batang atas yang di panen ketika sudah 35 hari setelah pindah tanam. Hasil rata-rata (Tabel 5) menyatakan bahwa perlakuan pembanding LO masih memberikan hasil yang paling tinggi dari semua perlakuan, sedangkan diantara perlakuan dibawah lampu LED yang mendapatkan hasil bobot segar panen tertinggi pada perlakuan L4 dengan berat $5,47 \mathrm{~g}$; diikuti dengan L2 seberat $4,28 \mathrm{~g}$; L3 seberat 2,47 g; dan L1 seberat 1,6 g. Menurut Manuhuttu (2014) Berat segar tanaman merupakan gabungan dari perkembangan dan pertambahan jaringan tanaman seperti jumlah daun, luas daun dan tinggi tanaman yang dipengaruhi oleh kadar air dan kandungan unsur hara yang ada di dalam sel-sel jaringan tanaman.

Tabel 5 Rata-rata bobot segar panen

\begin{tabular}{ccc}
\hline Perlakuan & Pencahayaan & Bobot Segar Panen (g) \\
\hline L0 & Cahaya Matahari & $31 \mathrm{~d}$ \\
L1 & LED 80\%M: 20\%B & $1,6 \mathrm{a}$ \\
L2 & LED 20\%M: 80\%B & $4,28 \mathrm{ab}$ \\
L3 & LED 50\%M: 50\%B & $2,47 \mathrm{ab}$ \\
L4 & LED 100\% Putih & $5,47 \mathrm{c}$
\end{tabular}

Keterangan: Angka yang diikuti huruf yang sama menunjukkan tidak berbeda nyata pada uji analisis ragam taraf $5 \%$.

\section{Panjang akar}

Panjang akar terpanjang (Tabel 6) dimiliki oleh perlakuan L0 dengan rerata sepanjang $53,32 \mathrm{~cm}$; sedangkan perlakuan di bawah cahaya LED hasil ratarata terpanjang diperoleh perlakuan L2 dengan panjang 
$34,17 \mathrm{~cm}$; diikuti dengan $\mathrm{L} 1$ rata-rata panjang akar 29,52 cm; L3 rata-rata panjang akar 21,29 cm dan L1 panjang rata-rata akar $14,32 \mathrm{~cm}$. Menurut Mas'ud (2009) pertumbuhan akar dipengaruhi dengan penyerapan nutrisi oleh tanaman dan akan mempengaruhi titik-titik meristem seperti panjang akar.

Tabel 6 Rata-rata panjang akar

\begin{tabular}{ccc} 
Perlakuan & Pencahayaan & Panjang Akar (cm) \\
\hline L0 & Cahaya Matahari & $53,32 \mathrm{~d}$ \\
L1 & LED 80\%M: 20\%B & $14,32 \mathrm{a}$ \\
L2 & LED 20\%M: 80\%B & $34,17 \mathrm{c}$ \\
L3 & LED 50\%M: 50\%B & $21,29 \mathrm{~b}$ \\
L4 & LED 100\% Putih & $29,57 \mathrm{c}$ \\
\hline
\end{tabular}

Keterangan: Angka yang diikuti huruf yang sama menunjukkan tidak berbeda nyata pada uji analisis ragam taraf $5 \%$

\section{Berat basah akar}

Hasil pada Tabel 7 menunjukkan tidak ada yang signifikan pada perlakuan LED. Berat basah akar terberat dimiliki oleh perlakuan L0 dengan rerata $2,47 \mathrm{~g}$ dari semua perlakuan; sedangkan perlakuan di bawah cahaya LED hasil rerata paling berat diperoleh perlakuan L4 dengan hasil 0,53 g; diikuti dengan L2 rerata berat $0,46 \mathrm{~g}$; $\mathrm{L} 3$ rerata dengan berat $0,39 \mathrm{~cm}$ dan L1 rerata dengan berat $0,29 \mathrm{~g}$. Sesuai dengan penjelasan Gardner et al (1991), bahwa pertumbuhan suatu tanaman diikuti dengan pertumbuhan bagian tanaman lainnya, dimana tajuk akan meningkat dengan mengikuti peningkatan berat akar. Pertumbuhan akar pada perlakuan LED belum optimal.

Tabel 7 Rata-rata berat basah akar

\begin{tabular}{ccc}
\hline Perlakuan & Pencahayaan & $\begin{array}{c}\text { Berat Basah Akar } \\
(\mathrm{g})\end{array}$ \\
\hline L0 & Cahaya Matahari & $2,47 \mathrm{~b}$ \\
L1 & LED 80\%M: 20\%B & $0,29 \mathrm{a}$ \\
L2 & LED 20\%M: 80\%B & $0,46 \mathrm{a}$ \\
L3 & LED 50\%M: 50\%B & $0,39 \mathrm{a}$ \\
L4 & LED 100\% Putih & $0,53 \mathrm{a}$
\end{tabular}

Keterangan: Angka yang diikuti huruf yang sama menunjukkan tidak berbeda nyata pada uji analisis ragam taraf $5 \%$.

\section{Berat kering brangkasan total}

Menurut Tabel 8 Berat kering brangkasan terberat dimiliki oleh perlakuan L0 dengan rerata $1,43 \mathrm{~g}$ dari semua perlakuan; sedangkan perlakuan di bawah cahaya LED hasil rerata paling berat diperoleh perlakuan L4 dengan hasil $0,32 \mathrm{~g}$; diikuti dengan L2 rerata berat $0,29 \mathrm{~g}$; $\mathrm{L} 3$ rerata dengan berat $0,18 \mathrm{~cm}$ dan $\mathrm{L} 1$ rerata dengan berat $0,14 \mathrm{~g}$. Berat kering total sangat ditentukan berat kering masing-masing organ yang menyusun tubuh tanaman Ginting (2010).
Tabel 8 Rata-rata berat kering brangkasan

\begin{tabular}{ccc}
\hline Perlakuan & Pencahayaan & $\begin{array}{c}\text { Berat Brangkasan } \\
\text { Total }(\mathrm{g})\end{array}$ \\
\hline L0 & Cahaya Matahari & $1,43 \mathrm{c}$ \\
L1 & LED 80\%M: 20\%B & $0,14 \mathrm{a}$ \\
L2 & LED 20\%M: 80\%B & $0,29 \mathrm{ab}$ \\
L3 & LED 50\%M: 50\%B & $0,18 \mathrm{ab}$ \\
L4 & LED 100\% Putih & $0,32 \mathrm{~b}$
\end{tabular}

Keterangan: Angka yang diikuti huruf yang sama menunjukkan tidak berbeda nyata pada uji analisis ragam taraf $5 \%$

\section{KESIMPULAN DAN SARAN}

\section{Kesimpulan}

1. Perlakuan L2 menunjukkan pertumbuhan yang lebih baik berdasarkan: tinggi tanaman, kandungan klorofil, dan panjang akar. Perlakuan dengan L4 menunjukkan pertumbuhan yang lebih baik berdasarkan jumlah daun, luas daun, bobot segar panen, berat basah akar, dan berat kering brangkasan total.

2. Hasil dibawah pencahayaan sinar matahari jauh lebih baik dari pada perlakuan pencahayaan LED. Hal ini terjadi karena intensitas cahaya LED kurang memenuhi dan kondisi lingkungan yang kurang terkontrol baik untuk tumbuh tanaman selada.

\section{DAFTAR PUSTAKA}

Ai NS. 2012. Evolusi fotosintesis pada tumbuhan. J. Ilmiah Sains 1(12): 28-34.

Aldaghi M, Anderson R, Lopez M, Odom H, Pearse M. 2016. Controlled environment for plant production. Thesis Biosystem Engineering. 11 May 2016. University of Arizona

Annisa, Febri, dan Leni. 2016. Urban farming bertani kreatif sayur, hias, \& buah. Jakarta: AgriFlo.

Bian ZH, Cheng RF, Yang QC, Wang J. 2016. Continuous light from red, blue, and green lightemitting diodes reduces nitrate content and enhances phytochemical concentrations and antioxidant capacity in lettuce. J. Amer. Soc. Hort. Sci. 141 (2): 186-195.

Carney MJ, Venetucci P, Gesick E. 2015. LED lighting in controlled environment agriculture. Minnesota Departement of Commerce. Outsourched Innovation LLC. URL:http://www.Outsourcedinnovation.com.

Gardner FP, Pearce RB, dan Mitchell RI. 1991. Fisiologi Tanaman Budidaya (Terjemahan). Jakarta: Universitas Indonesia Prees.

Ginting C. 2008. Pengaruh suhu zona perakaran terhadap pertumbuhan dan kadar klorofil tanaman selada sistem hidroponik. J. AGRIPLUS. No. 3(18): 169-178.

Ginting C. 2010. Kajian biologis tanaman selada dalam berbagai kondisi lingkungan pada sistem hidroponik. J. AGRIPLUS. No. 2(20): 107-113. 
He J, Qin L, Liu Y, Choong TW. 2015. Photosynthetic capacities and productivity of indoor hydroponically grown brassica alboglabra Bailey under different light sources. J. Amer. Plant Sci. 6: 554-563.

Hogewoning SW. 2010. On the photosynthetic and developmental response of leaves to the spectral composition of light. Wageningen University Wageninge Netherlands. p. 140.

Kobayashi K, Amore T, Lazaro M. 2013. Light-EmitingDiodes (LEDs) for miniatur hydrophonic lettuce. J. Optics and Photonics. 3: 74-77.

Kremes MR, Shchekin B, Mueller-Mach R, Mueller GO, Zhou L, Harbers G, Craford MG. 2007. Status and future of high-power light-emitting diodes for solidstate lighting. J. Display Techno. 3(2): 160-175.

Lin $\mathrm{KH}$, Huang MY, Huang WD, Hsu MH, Yang $\mathrm{ZH}$, Yang CM. 2012. The effect of red, blue, and white light-emitting diodes on the growth, development, and edible quality of hydroponically grown lettuce (Lactuca sativa L. var. capitata). J. Scientia Hortikulturae. 150: 86-91

Lindawati Y, Triyono S, Suhandy D. 2015. Pengaruh lama penyinaran komposisi lampu LED dan lampu neon terhadap pertumbuhan dan hasil tanaman pakcoy (Brassica rapa L.) dengan hiroponik sistem sumbu (wick system). J. Teknik Pertanian Lampung. 4(3): 191-200.

Manuhuttu AP, Rehatta H, Kailola JJG. 2014. Pengaruh konsentrasi pupuk hayati bioboost terhadap peningkatan produksi tanaman selada (Lactuca sativa. L). J. Agrologia. No. 3(1): 18-27.

Mas'ud H. 2009. Sistem hidroponik dengan nutrisi dan media tanam berbeda terhadap pertumbuhan dan hasil selada. J. Media Litbang Sulteng. 2(2): 131136.

Morrow RC. 2008. LED Lighting in Horticulture. J. Hort. Sci. 48 (7): 1947-1950.

Olle M. dan Virsille A. 2013. The effects of light-emitting diede lighting on greenhouse plant growth and quality. J. Agric Food Sci. 22: 223 - 234.
Pardo GP. Aguilar CH, Martinez FR, Pacheco FAD, Claudia LMG, Ortiz EJM. 2013. High intensity led light in lettuce seed physiology (Lactuca sativa L.). J. Acta Agrophysica. 20(4): 665-677.

Pinho P, Jokiken K, Halolen L. 2016. The influence of the LED light spectrum on the growth and nutrient uptake of hydroponically grown lettuce. J. Lighting Research and Technology. 49 (7): 866-881.

Promratrak L. 2017. The effect of using LED lighting in the growth of crops hydroponics. Int. J. Smart Grid and Clean Energy. 6(2): 133-140.

Restiani AR, Triyono S, Tusi A, Zahab R. 2015. Pengaruh jenis lampu terhadap pertumbuhan dan hasil produksi tanaman selada (Lactuca sativa L.) dalam sistem hidroponik indoor. Jurnal teknik pertanian Lampung. 4 (3): 219 - 226.

Sarkar A and Majumder M. 2013. Opportunities and Challenges in Sustainability of Vertical EcoFarming: A Review. J. of Advanced Agricultural Technologies. 2 (2): 98 - 105.

Sasmitamihardja D dan AH Siregar. 1996. Fisiologi Tumbuhan. Proyek Pendidikan Akademik Dirjen Dikti. Bandung: Depdikbud.

Siregar J, Triyono S, Suhandy D. 2015. Pengujian beberapa nutrisi hidroponik pada selada (Lactuca sativa L.) dengan teknologi hidroponik sistem terapung (THTS) termodifikasi. J. Teknik Pertanian Lampung 4(1): 65-72.

Syafriyuddin. 2015. Pengaruh variabel warna lampu led terhadap pertumbuhan tanaman krisan. Dalam Priyambondo S, Saudah S, dan Ledhe NT. Prosiding seminar nasional teknik industri Sustainable Manufacturing. Yogyakarta, 3 Sep 2015. Institut Sains dan Teknologi AKPRIND.

Zakrzewska AS, Kleiber T. 2014. The effect of light colour and type of lamps on rooting and nutrient status in cuttings of Michaelmas daisy. Bulg. J. Agric. Sci. 20: 1426-1434. 